\title{
The Development of Local Culture Based Teaching Materials with Constructivism Approach to Improve the Thinking Ability and Mathematics Disposition of Student
}

\author{
Sri Rahma Yani Harahap ${ }^{1}$, Izwita Dewi², Mulyono ${ }^{3}$ \\ ${ }^{1}$ Postgraduate Program in State University of Medan, Indonesia \\ ${ }^{2,3}$ State University of Medan, Indonesia \\ srirahmayaniharahap@gmail.com
}

\begin{abstract}
This research is a development research conducted at SMP N 2 Panyabungan which aims to find out how; 1) the level of validity, effectiveness and practicality of teaching materials developed in improving students' mathematical reasoning abilities and dispositions;

$2\}$ Increasing students' mathematical reasoning skills and dispositions in the application of local culture-based teaching materials with a constructivism approach. This research produces teaching materials based on local culture with a constructivism approach that is carried out according to the Dick \& Carey development model procedure. The results of this study are the local culture-based teaching materials developed are; 1) valid, both this validity and construct, 2) effective, seen from the completeness of learning and student activities; 3) practical, seen from the validator's assessment and students' positive responses to the teaching materials developed; 4) to increase students' mathematical reasoning abilities in the application of teaching materials based on local culture, namely $0.19 ; 5)$ the improvement of students' mathematical disposition abilities in the development of teaching materials, namely 0.43 .
\end{abstract}

Keywords development of teaching materials; culture-based learning; reasoning; dispositions

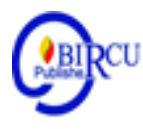

\section{Introduction}

The world of education, especially mathematics, has become a major concern from various circles. This can be seen from the mathematics subjects that are always taught at every level of education from elementary to high school, and there are even several departments in universities that teach mathematics.

This is only natural considering the mathematical abilities that accustom students to explore, construct conjectures, provide logical reasons, the ability to solve non-routine problems, communicate ideas about mathematics, use mathematics as a communication tool, connect ideas in mathematics, between mathematics and other intellectual activities. In other words, the term mathematical power includes the ability to understand, solve problems, connect, communicate and reason mathematically.

Reasoning, which is a mathematical ability that needs to be developed among students, is a high-level stage of mathematical thinking, which includes the capacity to think logically and systematically. Amiopour et al, (2012: 2916) state reasoning as the act of using reason to get a conclusion from a certain place. Furthermore, Lithner (2012: 3) argues that reasoning skills and conceptual understanding are the key to learning objectives. This is also in line with the statements of Shivakumar and Sarvna (2014: 1), namely: 
Reasoning skills develop gradually though a person's lifetime and at different rates for different individuals ... Reasoning skills are recognized as the key abilities for human being to create, learn and exploit knowledge. These skills are also an important factor in the process of human civilization. Therefore, the importance of reasoning skills has been of great concern in educational settings and the world of work.

The statement above shows that the ability to reason is the main ability for humans to create, learn and exploit knowledge and the ability to reason develops gradually. Therefore, reasoning is important to consider in educational settings and the world of work. Mathematics can develop a mindset that involves critical, systematic, logical and creative thinking. By learning mathematics students can draw conclusions from some of the data they get or know. The ability to reason is not only needed by students when they are studying mathematics and other subjects, but it is very necessary for every human being when solving problems or when making decisions.

However, in reality mathematics learning currently adheres to an orthodox way where learning is dominated by teachers and does not provide access for students to develop independently through learning activities that prioritize concept discovery. Students tend to memorize only a number of material and problem-solving steps that have been done by the teacher or in textbooks. This is in line with the results of an interview with one of the mathematics teachers at SMPN 2 Panyabungan who said that, "Class IX students' mathematical reasoning ability is still low, this can be seen from the results of student tests, more than 50\% of grade IX students in the 2015 academic year / 2016 which has not reached the set learning completeness value, namely 65 and therefore remedial is carried out ".

Furthermore, previous research conducted by Putri in 2011 regarding the reasoning abilities of junior high school students through realistic mathematics learning also only obtained an average score of $48.17 \%$ of the ideal score, Wachyar in 2012 through his research using a contextual approach, obtained average results. posttest reasoning ability of $56.3 \%$ of the ideal score. Likewise, research conducted by Siregar in 2011, the mathematical reasoning ability of junior high school students through the Geogebra-assisted Pace model learning was $59.44 \%$.

\section{Review of Literatures}

In addition to students' mathematical reasoning abilities as a cognitive aspect, affective aspects also need to be considered. One of them is the students' mathematical disposition.Wardani (2008: 15) suggests that mathematical disposition is an interest and appreciation of mathematics, namely the tendency to think and act positively, including selfconfidence, curiosity, persistence, enthusiasm for learning, persistence in facing problems, flexible, willing to share with others, reflective in mathematical activities (doing math). According to (Adliani, 2020) students have difficulty in solving problems understanding mathematical concepts. One of the mathematical skills that students must possess and achieve is problem solving (Pohan, 2020). Furthermore, according to Mulyana (2009: 19) mathematical disposition is a change in the tendency of students to view, behave and act when learning mathematics. For example, when students solve non-routine problems, their attitudes and beliefs as a student become more positive. The more mathematical concepts understood, the more confident that mathematics can be mastered. Other than that,Sumarmo (2012: 2) says that someone who has a high mathematical disposition will form individuals 
who are tough, resilient, responsible, have high achievement motives, and help individuals achieve their best results. It is not uncommon for the younger generation not to know the characteristics of their region, but when asked about the characteristics of a foreign country they are spontaneous in conveying it, both in terms of livelihood, means of transportation and language. If this continues, gradually it is not impossible that our younger generations will not recognize and even forget their own culture. According to Sachari (2009: 7) this condition is exacerbated by the weakness of the value inheritance program, so that there is a process of degrading values among the younger generation. The Problem Based Learning Model helps to enhance the development of learning skills in an open, reflective, critical, active mindset, and facilitates the success of problem solving, communication, group work, and creates better interpersonal skills than other models (Rusman in Nasution, 2020).

Based on the results of observations made at SMPN 2 Payabungan, it can be seen that the textbooks used do not include aspects of students 'learning and dispositions, so it is thought that they have not been able to improve students' mathematical reasoning abilities and dispositions.

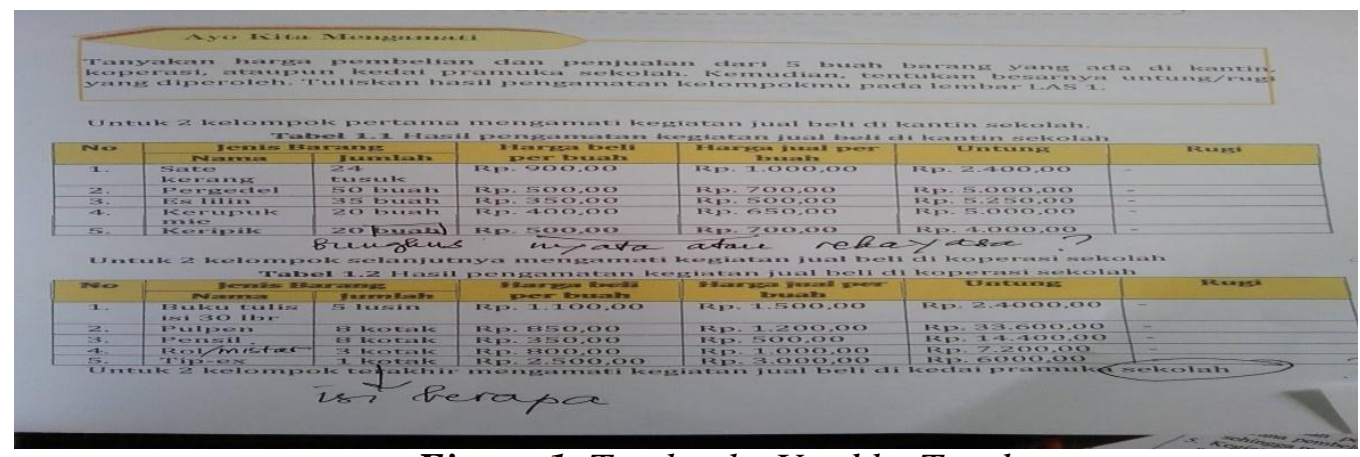

Figure 1. Textbooks Used by Teachers

Furthermore, from the figure below, it can be seen that the RPP used is less effective. It can be seen from the teacher's activities and student activities that are not explained separately and in detail as well as the selection of learning methods that are still teachercentered.
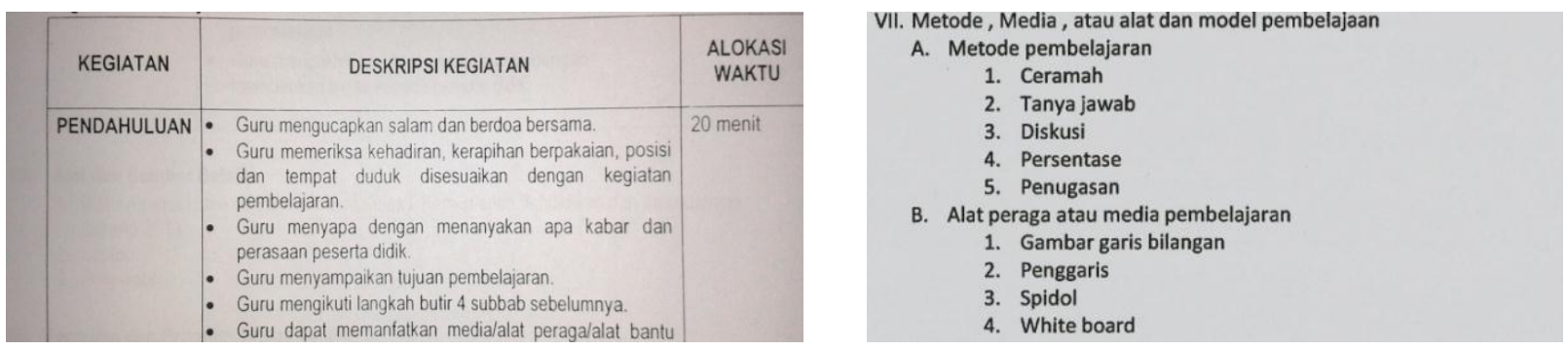

Figure 2. RPP Prepared by the Teacher

According to Tarigan (2020), learning with student worksheets can make the learning process more effective as expected in each learning that is increasing the creativity of students' thinking so that learning objectives are achieved. Teaching materials used in learning also use LKS books (student activity sheets) that are distributed by the school. The worksheets used tend to be ready-to-use worksheets whose contents lead to material conclusions and there is no cultural element at all. 


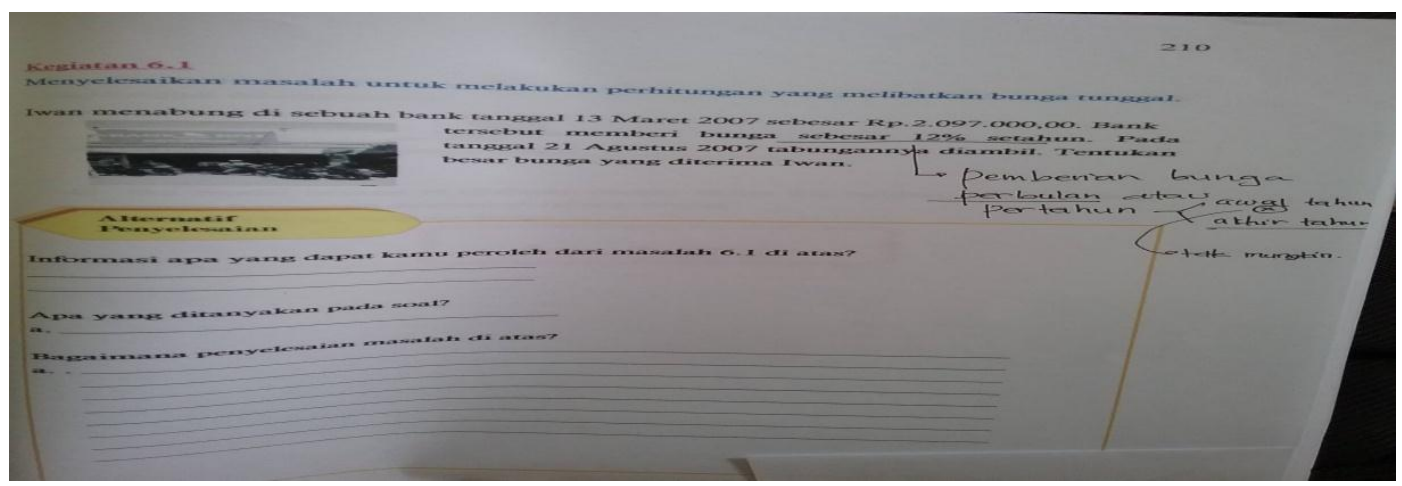

Figure 3. LKS Used by Students

Based on the background of the problem above, the identification of the problem in this study is the firstMathematics learning in class IX at SMPN 2 Panyabungan is still centered on the teacher, the two students in grade IX at SMPN 2 Panyabungan are not actively involved in the learning process. Third, the mathematical reasoning ability of students in class IX at SMPN 2 Panyabungan is still low. Fourth, the mathematical disposition ability of students in class IX at SMPN 2 Panyabungan is still low. The teaching materials used in class IX at SMPN 2 Panyabungan do not yet cover the aspects of students' mathematical disposition abilities.

\section{Research Method}

Based on the formulation of the problem and the stated research objectives, this research is categorized into the type of development research (development research) with the Thiagarajan learning device development model. Researchers develop teaching materials based on local culture on the material of the Two-Variable Linear Equation System, while the product of this research is a local culture-based teaching material with an effective constructivism approach along with all the research instruments needed for the process of developing these teaching materials. The teaching materials developed in this study were Teacher Books (BG) and Student Books (BS).

\section{Result and Discussion}

\subsection{Results}

This research is a development research conducted at SMP N 2 Panyabungan. The results of this study are in the form of local culture-based teaching materials with a constructivist approach. This study aims to determine the level of validity and effectiveness of the teaching materials developed in improving students' mathematical reasoning abilities and dispositions. In addition, this study also aims to determine how to improve students' rationalizing abilities and mathematical dispositions in the application of teaching materials based on local culture with a constructivism approach. The development of local culturebased teaching materials with a constructivism approach in this study was carried out in accordance with the Dick \& Carey development model procedure. 
a. Description of the Development of Local Culture-Based Teaching Materials with a Constructivism Approach

Teaching materials based on local culture with a constructivism approach developed in this study are teaching materials based on local culture with a constructivist approach with material on the System of Two Variable Linear Equations.

\section{b. Identify Instructional Goal ( $s$ ) (Identification of Learning Objectives)}

The results of the reasoning ability test obtained can be seen in table 1 below:

Table 1. Results of Student Knowledge Analysis for Ability Tests Mathematical Problem Solving

\begin{tabular}{|c|c|c|c|}
\hline $\begin{array}{c}\text { Knowledge } \\
\text { Completeness } \\
\text { Value (letters) }\end{array}$ & $\begin{array}{c}\text { Many } \\
\text { Students }\end{array}$ & $\begin{array}{c}\text { Percentage } \\
(\boldsymbol{\%})\end{array}$ & Information \\
\hline A & 0 & 0 & Completed \\
\hline B & 6 & 30 & Completed \\
\hline C & 10 & 50 & Not complete \\
\hline D & 4 & 20 & Not complete \\
\hline Total & 20 & 100 & \\
\hline
\end{tabular}

From table 1, it is known that as many as four students (20\%) obtained a D grade, as many as ten students (50\%) obtained a C grade, six students $(30 \%)$ obtained a B grade and no student received an A. or $30 \%$ who complete (get a minimum grade of B). Likewise, the results of the analysis of students' knowledge for the mathematical disposition ability test were obtained, as shown in table 2 below:

Table 2. Results of Student Knowledge Analysis for Tests Mathematical Connection Capability

\begin{tabular}{|c|c|c|c|}
\hline $\begin{array}{c}\text { Knowledge } \\
\text { Completeness } \\
\text { Value (letters) }\end{array}$ & $\begin{array}{c}\text { Many } \\
\text { Students }\end{array}$ & $\begin{array}{c}\text { Percentage } \\
(\boldsymbol{\%})\end{array}$ & Information \\
\hline $\mathrm{A}$ & 0 & 0 & Completed \\
\hline $\mathrm{B}$ & 5 & 25 & Completed \\
\hline $\mathrm{C}$ & 9 & 45 & Not complete \\
\hline $\mathrm{D}$ & 6 & 30 & Not complete \\
\hline Total & 20 & 100 & \\
\hline
\end{tabular}

From table 2 it is known that as many as six students (30\%) got a D grade, nine students $(45 \%)$ got a C, five students $(25 \%)$ got a B grade and no student got an A. minimum grade of B) only five students or $25 \%$. From these results, it can be seen that the students' mathematical disposition ability is still low. The problem of low reasoning ability and mathematical disposition is caused by the lack of knowledge and skills of students in reasoning such as making assumptions, performing mathematical manipulations, compiling evidence and drawing conclusions from statements.

\section{c. Develop Instructional Strategy (Developing Learning Strategies)}

Based on the five previous stages, it will then be identified which will be used to achieve the final goal. The learning approach developed is based on local culture. The 
constructivism approach consists of five stages, namely: activating existing knowledge, acquiring new knowledge, understanding knowledge, applying knowledge that has been acquired and reflecting. The constructivist approach stage is described in table 3 .

Table 3. Constructivism Approach

\begin{tabular}{|c|c|}
\hline Step & Activity Description \\
\hline $\begin{array}{c}\text { Activation of } \\
\text { existing } \\
\text { knowledge }\end{array}$ & $\begin{array}{l}\text { Students are asked to remember the knowledge they already have such as } \\
\text { prerequisite knowledge on the material to be studied. For example by asking: } \\
\text { a. What do you know about two-variable systems of linear equations? } \\
\text { b. How much is the number of a pencil if you give } 5 \text { pencils for Rp. } 5,000 \text { ? }\end{array}$ \\
\hline $\begin{array}{c}\text { acquisition of } \\
\text { new } \\
\text { knowledge }\end{array}$ & $\begin{array}{l}\text { Students are asked to discover new knowledge independently by asking students to } \\
\text { find information about: } \\
\text { a. how can you solve this? } \\
\text { b. is the way you do it right? } \\
\text { c. how should you solve this problem? } \\
\text { d. what information is important to remember? } \\
\text { e. should i do it a different way? } \\
\text { f. If you don't understand, what needs to be done? }\end{array}$ \\
\hline $\begin{array}{l}\text { understanding } \\
\text { of knowledge }\end{array}$ & $\begin{array}{l}\text { Students are asked to solve problems and discover new knowledge they already } \\
\text { have by asking students to find information about: } \\
\text { a. how is the concept carried out in this case? } \\
\text { b. is the way i do it right? } \\
\text { c. how should i solve this problem? } \\
\text { d. what information is important to remember? } \\
\text { e. should i do it a different way? } \\
\text { If you don't understand, what needs to be done? }\end{array}$ \\
\hline $\begin{array}{l}\text { Apply the } \\
\text { knowledge } \\
\text { and } \\
\text { understanding } \\
\text { gained }\end{array}$ & $\begin{array}{l}\text { Students are invited to evaluate actions by asking students to gather various } \\
\text { information about: } \\
\text { a. Check if what you are doing is done correctly } \\
\text { b. is my way of thinking producing more or less what I expected? } \\
\text { c. Work on this problem in different ways } \\
\text { d. how do you apply this way of thinking to other problems? } \\
\text { e. Rework this assignment to fill in the "blanks" of your understanding }\end{array}$ \\
\hline Reflect & $\begin{array}{l}\text { Students are invited to make problems related to their surroundings and solve them } \\
\text { with the knowledge and understanding that students already have by asking students } \\
\text { to collect various information about: } \\
\text { give one problem and solve it with the understanding you already have. }\end{array}$ \\
\hline
\end{tabular}

\section{d. One-on-one Evaluation by Experts (Validation)}

The one-on-one evaluation by this expert was carried out by the researcher asking as many as five validators to validate the mathematics module. The validators consisted of three lecturers of the UNIMED Postgraduate Mathematics Education Study Program and two mathematics teachers.PeThe values carried out on teaching materials include aspects: format, language and content of teaching materials. Teaching materials in this study were in the form of teacher books, student books and student activity sheets. The results of expert validation of teaching materials can be seen as in the following table: 
Table 4. Results of Validation of Teacher Books

\begin{tabular}{|l|c|c|}
\hline \multicolumn{1}{|c|}{ Aspect } & $\begin{array}{c}\text { Average of Each } \\
\text { Aspect }\end{array}$ & \multirow{2}{*}{ Average Total (Va) } \\
\hline Format & 4.50 & \multirow{2}{*}{4} \\
\cline { 1 - 2 } Language & 4.36 & \\
\cline { 1 - 2 } Contents & 4.35 & \\
\cline { 1 - 2 } Illustration & 4.46 & \\
\hline
\end{tabular}

The validity criteria are as follows:
$1 \leq \mathrm{Va}<2$
: invalid
$2 \leq \mathrm{Va}<3$
: less valid
$3 \leq \mathrm{Va}<4$
: quite valid
$4 \leq \mathrm{Va}<5$
: valid
$\mathrm{Va}=5$
: very valid

Based on Table 4, it can be seen that the total average validator of teaching materials in the form of teacher's books is at the interval: $4 \leq \mathrm{Va}<5$. Based on the validity criteria, it can be said that the teaching materials in the form of developed teacher books are valid.

Table 5. Student Book Validation Results

\begin{tabular}{|l|c|c|}
\hline \multicolumn{1}{|c|}{ Aspect } & $\begin{array}{c}\text { Average of Each } \\
\text { Aspect }\end{array}$ & \multirow{2}{*}{ Average Total (Va) } \\
\hline Format & 4.35 & \multirow{2}{*}{4} \\
\cline { 1 - 2 } Language & 4.28 & \multirow{2}{*}{4.52} \\
\hline Contents & 4.9 & \\
\cline { 1 - 2 } Illustration & 4.53 & \\
\hline
\end{tabular}

The validity criteria are as follows:

$\begin{array}{ll}1 \leq \mathrm{Va}<2 & : \text { invalid } \\ 2 \leq \mathrm{Va}<3 & : \text { less valid } \\ 3 \leq \mathrm{Va}<4 & : \text { quite valid } \\ 4 \leq \mathrm{Va}<5 & \text { : valid } \\ \mathrm{Va}=5 & \text { : very valid }\end{array}$

Based on Table 5 it is obtained that the average total validator of teaching materials in the form of student books is at the interval: $4 \leq \mathrm{Va}<5$. Based on the validity criteria, it can be said that the teaching materials in the form of student books developed are valid.

Table 6. Results of Student Activity Sheet Validation

\begin{tabular}{|l|c|c|}
\hline Aspect & $\begin{array}{c}\text { Average of Each } \\
\text { Aspect }\end{array}$ & Average Total (Va) \\
\hline Format & 4.50 & 4.4 \\
\hline Contents & 4.36 & \\
\hline
\end{tabular}


The validity criteria are as follows:

$$
\begin{array}{ll}
1 \leq \mathrm{Va}<2 & \text { : invalid } \\
2 \leq \mathrm{Va}<3 & \text { : less valid } \\
3 \leq \mathrm{Va}<4 & \text { : quite valid } \\
4 \leq \mathrm{Va}<5 & \text { : valid } \\
\mathrm{Va}=5 & \text { : very valid }
\end{array}
$$

Based on table 6 , the total average validator of teaching materials in the form of student activity sheets is at the interval: $4 \leq \mathrm{Va}<5$. Based on the validity criteria, it can be said that the teaching materials in the form of student activity sheets developed are valid. The results of the validation of the learning tools will be described as follows:

Table 7. Validation Results Learning Implementation Plan (RPP)

\begin{tabular}{|l|c|c|}
\hline \multicolumn{1}{|c|}{ Aspect } & $\begin{array}{c}\text { Average of Each } \\
\text { Aspect }\end{array}$ & Average Total (Va) \\
\hline Format & 4.20 & 4.24 \\
\hline Language & 4.26 & \\
\hline Contents & 4.29 & \\
\hline
\end{tabular}

The validity criteria are as follows:

$$
\begin{array}{ll}
1 \leq \mathrm{Va}<2 & \text { : invalid } \\
2 \leq \mathrm{Va}<3 & \text { : less valid } \\
3 \leq \mathrm{Va}<4 & \text { : quite valid } \\
4 \leq \mathrm{Va}<5 & \text { : valid } \\
\mathrm{Va}=5 & \text { : very valid }
\end{array}
$$

\begin{tabular}{|c|c|c|c|c|c|c|}
\hline \multirow[t]{2}{*}{ No. } & \multirow[t]{2}{*}{ Validator } & \multicolumn{5}{|c|}{$\begin{array}{c}\text { Validator's Assessment for Each } \\
\text { Question Item }\end{array}$} \\
\hline & & 1 & 2 & 3 & 4 & 5 \\
\hline 1 & $\mathrm{I}$ & RK & RK & $\overline{\mathrm{RK}}$ & RK & RK \\
\hline 2 & II & TR & TR & TR & RK & $\begin{array}{c}\text { Kinde } \\
\text { rgarte } \\
\text { n }\end{array}$ \\
\hline 3 & III & RK & RK & RK & RK & RK \\
\hline 4 & IV & TR & TR & $\overline{\mathrm{RK}}$ & TR & TR \\
\hline 5 & $\mathrm{~V}$ & TR & TR & TR & TR & TR \\
\hline
\end{tabular}

Based on the results of the validation, it was found that the total validity average of mathematics lesson plans was at the interval: $4 \leq \mathrm{Va}<5$. Based on the validity criteria, it could be said that the mathematics RPP was made "valid". Based on the sheet that has been validated by the validator, it was found that some validators stated that the lesson plan can be used with minimal revision and without revision.

Table 8. Results of the Pretest Validation of Mathematical Reasoning Ability

Information:

TR = Can be used without revision

$\mathrm{RK}=$ Dapat is used with minor revisions 
Table 9. The Results of Post-Test Validation of Mathematical Reasoning Ability

\begin{tabular}{|c|l|c|c|c|c|c|}
\hline \multirow{2}{*}{ No. } & \multirow{2}{*}{ Validator } & \multicolumn{5}{|c|}{ Validator's Assessment for Each } \\
& & \multicolumn{5}{|c|}{ Question Item } \\
\cline { 3 - 7 } & & $\mathbf{1}$ & $\mathbf{2}$ & $\mathbf{3}$ & $\mathbf{4}$ & $\mathbf{5}$ \\
\hline 1 & I & TR & TR & RK & TR & TR \\
\hline 2 & II & TR & RK & TR & RK & TR \\
\hline 3 & III & TR & RK & RK & RK & RK \\
\hline 4 & IV & TR & TR & TR & TR & TR \\
\hline 5 & V & TR & TR & TR & TR & TR \\
\hline
\end{tabular}

Information:

TR = Can be used without revision

RK = Dapat is used with minor revisions

\section{e. Field Trials}

The first trial was conducted 3 times in accordance with the learning implementation plan (RPP) that had been developed with a total of 32 students. This trial was conducted to measure the practicality and effectiveness of teaching materials developed based on local culture with a constructive approach to improve students' mathematical reasoning abilities and dispositions. In this trial, the researcher acted as an observer in charge of observing student activity and the ability of the teacher to manage learning and the teacher in this study was a subject teacher who handled class VIII-1.

\section{f. Data Validity of Teaching Materials}

1. Validity of Students' Mathematical Reasoning Ability Test Items

The test of students 'reasoning ability tests aims to determine the validity and reliability as well as the level of difficulty of the students' mathematical reasoning ability test questions. This will affect the alignment with the total score so that it can be used as a tool for evaluating mathematical reasoning abilities at the end of learning. The test of validity, reliability and level of difficulty of the test is carried out by testing other students with the same characteristics.

Based on the product moment correlation formula, the validity of each test item is shown in Tables 10 and 11 as follows:

Table 10. Validity of Mathematical Reasoning Ability Test Items (Pre-test)

\begin{tabular}{|c|c|c|c|c|}
\hline No. & $r_{x y}$ & $t_{\text {hitung }}$ & $t_{\text {tabel }}$ & Interpretation \\
\hline 1 & 0.816 & 7,725 & 2,042 & Significant / Valid \\
\hline 2 & 0.825 & 7,988 & 2,042 & Significant / Valid \\
\hline 3 & 0.800 & 7,295 & 2,042 & Significant / Valid \\
\hline 4 & 0.719 & 5,662 & 2,042 & Significant / Valid \\
\hline 5 & 0.629 & 4,435 & 2,042 & Significant / Valid \\
\hline
\end{tabular}


Table 11. The Validity of Mathematical Reasoning Ability Test Items (Post-test)

\begin{tabular}{|c|c|c|c|c|}
\hline No. & $r_{x y}$ & $t_{\text {hitung }}$ & $t_{\text {tabel }}$ & Interpretation \\
\hline 1 & 0.787 & 6,986 & 2,042 & Significant / Valid \\
\hline 2 & 0.753 & 6,266 & 2,042 & Significant / Valid \\
\hline 3 & 0.823 & 7,398 & 2,042 & Significant / Valid \\
\hline 4 & 0.810 & 7,556 & 2,042 & Significant / Valid \\
\hline 5 & 0.660 & 4,814 & 2,042 & Significant / Valid \\
\hline
\end{tabular}

Based on the data in the table above, the interpretation of each test item is in the Valid category. Thus, all the test items can be said to be suitable for use.

g. The Ability of Teachers to Manage Learning Using the Developed TeachingMaterials

Teacher observations in managing learning are carried out every meeting that is observed by an observer. The following is the teacher's observation data managing learning:

Table 12. Average Assessment of Teacher Ability to Manage Learning in Trials I

\begin{tabular}{|c|c|c|c|c|c|c|}
\hline \multirow[t]{2}{*}{ No. } & \multirow[t]{2}{*}{ Aspect } & \multirow[t]{2}{*}{ Activities } & \multicolumn{2}{|c|}{$\begin{array}{c}\text { Average } \\
\text { Observer } \\
\text { Value }\end{array}$} & \multicolumn{2}{|c|}{ Average Value } \\
\hline & & & $\mathbf{I}$ & II & Activities & Aspect \\
\hline \multirow{3}{*}{1.} & \multirow{3}{*}{ Preliminary } & $\begin{array}{l}\text { Convey learning objectives and } \\
\text { motivate students }\end{array}$ & 5 & 5 & (1) & \multirow{3}{*}{4,4} \\
\hline & & Perform apperception activities & 4 & 4 & 4 & \\
\hline & & $\begin{array}{l}\text { Deliver basic competencies } \\
\text { and indicators to be achieved } \\
\text { as well as activity plans }\end{array}$ & 4,3 & 4,3 & 4,3 & \\
\hline \multirow{3}{*}{2.} & \multirow{3}{*}{$\begin{array}{c}\text { Core } \\
\text { Activities }\end{array}$} & $\begin{array}{l}\text { Helping students form their } \\
\text { own new knowledge by asking } \\
\text { students to read and understand } \\
\text { student books up to page } 4 \text { and } \\
\text { solve the problems in the book } \\
\text { independently. }\end{array}$ & 4,3 & 3,3 & 3.8 & \multirow{3}{*}{4.04} \\
\hline & & $\begin{array}{l}\text { Ask students what the } \\
\text { alternatives that students work } \\
\text { on have the same result as } \\
\text { alternative solutions to the } \\
\text { above problems }\end{array}$ & 4,7 & 3,7 & 4,2 & \\
\hline & & $\begin{array}{l}\text { Guide students to share the } \\
\text { results of their discussions with } \\
\text { small groups of } 4 \text { people to } \\
\text { discuss the truth of the } \\
\text { concepts they get during the } \\
\text { discussion in pairs, then } \\
\text { provide opportunities for group } \\
\text { representatives to present the } \\
\text { results of the discussion and } \\
\text { other groups to respond. }\end{array}$ & 4 & 4,3 & 4,2 & \\
\hline
\end{tabular}




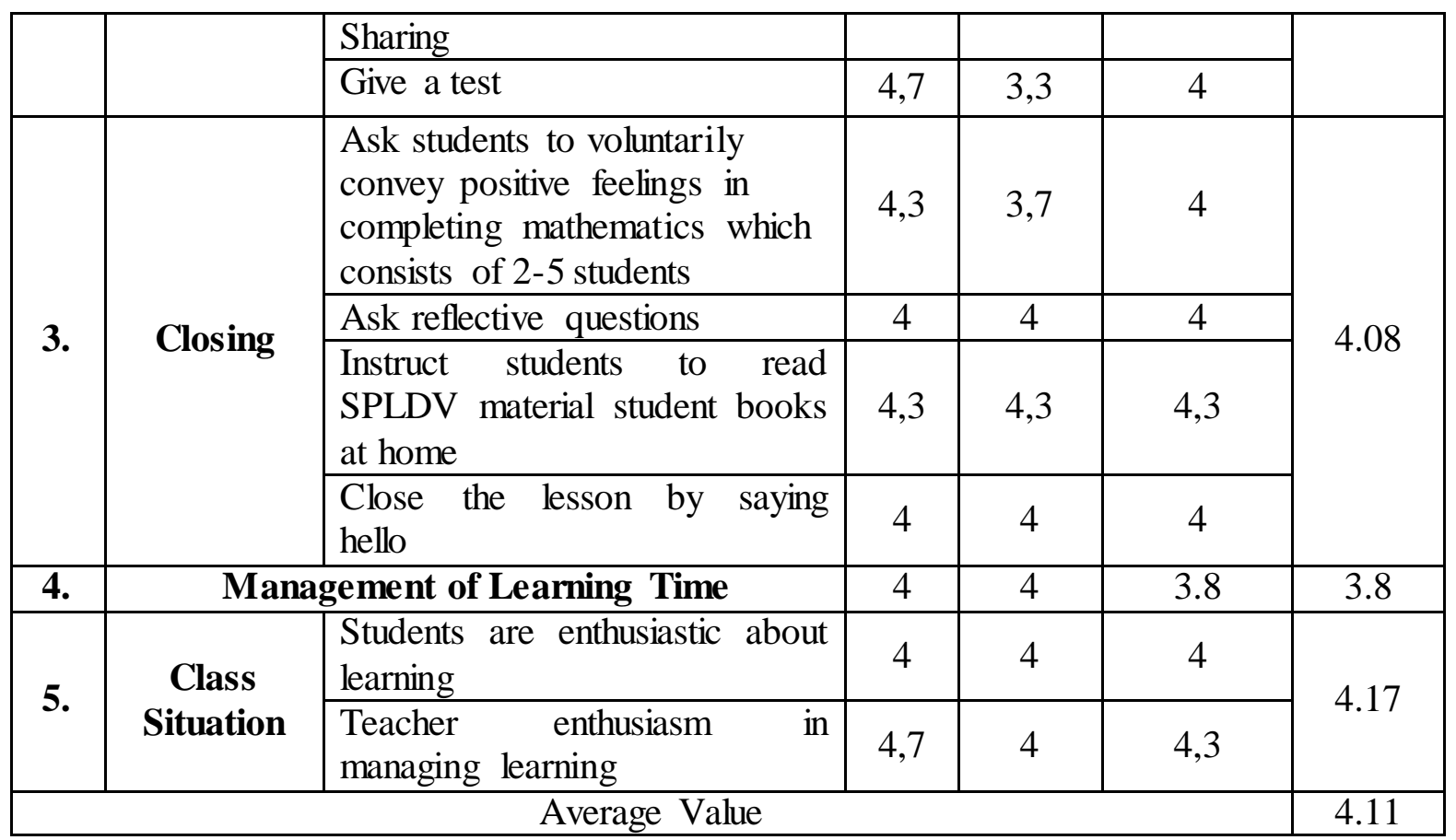

From table 12 above, the highest score is the teacher's ability to manage preliminary or early learning activities, namely 4.4 while the lowest score is the teacher's ability to manage learning time, namely 3.8. The value of the teacher's ability in core activities is 4.04, closing activities is 4.08 and the ability to manage the classroom atmosphere is 4.17 .

\section{h. Learning Device Effectiveness Data}

1. Students' Mathematical Reasoning Ability Tests

The mathematical reasoning ability test is carried out once at the end of the lesson after carrying out three meetings of teaching and learning activities. Giving the test aims to determine the increase in mathematical reasoning skills obtained by students after being given learning treatment using a constructivism approach on the material of two-variable linear equation systems. The average value on each indicator can be seen in table 13 below:

Table 13. Results of Mathematical Reasoning Ability Tests for Each Aspect on Tests I

\begin{tabular}{|c|c|c|c|}
\hline No. & $\begin{array}{l}\text { Question } \\
\text { Number }\end{array}$ & $\begin{array}{c}\text { Average } \\
\text { Value }\end{array}$ & Reasoning Indicator \\
\hline 1. & 1 & 65,625 & $\begin{array}{l}\text { - Ability to present mathematical statements orally, } \\
\text { in writing, pictures, and diagrams } \\
\text { - Ability to make guesses }\end{array}$ \\
\hline 2. & 2 & 69,375 & $\begin{array}{l}\text { - Ability to present mathematical statements orally, } \\
\text { in writing, pictures, and diagrams } \\
\text { - Ability to make guesses } \\
\text { - Ability to perform mathematical manipulations }\end{array}$ \\
\hline 3. & 3 & 63,125 & - Ability to perform mathematical manipulations \\
\hline 4. & 4 & 68,125 & - Ability to draw conclusions from statements \\
\hline 5. & 5 & 71,875 & $\begin{array}{l}\text { - Ability to compile evidence, provide reasons for a } \\
\text { solution } \\
\text { - Ability to draw conclusions from statements }\end{array}$ \\
\hline
\end{tabular}


From the table 4.16 above, it can be seen that the highest average value is 71.875 , namely the indicator of the ability to compile evidence, provide reasons for a solution and the ability to draw conclusions from statements. While the lowest average score is an indicator of the ability to perform mathematical manipulation and the ability to compile evidence, giving reasons for a solution, namely 63.125. The average of the other three indicators is 65,625 , 69,375 and 68,125 .

The complete N-Gain results for improving reasoning skills in the first trial can be seen in the attachment. In the appendix, it can be seen that the total pre-test score of students' mathematical reasoning ability is 1950 from a maximum score of 3200 . While the total posttest score of 32 students' mathematical reasoning ability is 2580. Based on this score, we can see that the N-Gain of students' mathematical reasoning abilities as follows:

$$
\begin{aligned}
\text { Gain Ternormalisasi }(g) & =\frac{\text { posttestscore }- \text { pretestscore }}{\text { maximumscore }- \text { pretest }} \\
& =\frac{2580-1950}{3200-1950} \\
& =\frac{73}{152} \\
& =0.504
\end{aligned}
$$

The N-Gain value is 0.504 if interpreted into the classification described, and then the total increase in reasoning ability in the first trial obtained is in the "moderate" category. The $\mathrm{N}$-Gain value for an indicator of the mathematical reasoning ability of each student is 0,11 ; $0.53 ; 0.63$ and 0.54 . The indicator with the lowest increase was the first indicator with an NGain value of 0.11 , namely: drafting a concept. While the indicator that experienced the highest increase was the indicator of compiling evidence with an N-Gain value of 0.63 .

\section{i. Students' Mathematical Reasoning Ability Test on Trial II}

The mathematical reasoning ability test is carried out once at the end of the lesson after carrying out three meetings of teaching and learning activities. Giving the test aims to determine the increase in mathematical reasoning skills obtained by students after being given learning treatment using a constructivism approach on the material of two-variable linear equation systems. The data on test results II for mathematical reasoning skills can be seen in the table below:

Table 14. Completeness Level of Students' Mathematical Reasoning Ability Tests in Trial II

\begin{tabular}{|c|c|c|}
\hline Category & $\begin{array}{c}\text { The Number of } \\
\text { Students }\end{array}$ & $\begin{array}{c}\text { Percentage of } \\
\text { Classical } \\
\text { Completeness }\end{array}$ \\
\hline Completed & 30 & $93.75 \%$ \\
\hline Not complete & 2 & $6.25 \%$ \\
\hline amount & 32 & $100 \%$ \\
\hline Class Average & \multicolumn{2}{|c|}{73.5} \\
\hline
\end{tabular}

From table 14 it can be analyzed that only 2 students did not complete the KKM, namely 60 and 30 students. The average score on the mathematical reasoning ability test was 73.5 with classical completeness reaching $93.75 \%$. The average value for each indicator can be seen in the following table: 
Table 15. Results of the Mathematical Reasoning Ability Test

\begin{tabular}{|c|c|c|c|}
\hline No. & $\begin{array}{l}\text { Question } \\
\text { Number }\end{array}$ & $\begin{array}{l}\text { Average } \\
\text { Value }\end{array}$ & Reasoning Indicator \\
\hline 1. & 1 & 80,625 & $\begin{array}{l}\text { - Ability to present mathematical statements } \\
\text { orally, in writing, pictures, and diagrams } \\
\text { - Ability to make guesses }\end{array}$ \\
\hline 2. & 2 & 73,125 & $\begin{array}{l}\text { - Ability to present mathematical statements } \\
\text { orally, in writing, pictures, and diagrams } \\
\text { - Ability to make guesses } \\
\text { - Ability to perform mathematical manipulations }\end{array}$ \\
\hline 3. & 3 & 67.5 & - Ability to perform mathematical manipulations \\
\hline 4. & 4 & 71.25 & - Ability to draw conclusions from statements \\
\hline 5. & 5 & 75 & $\begin{array}{l}\text { - Ability to compile evidence, provide reasons for } \\
\text { a solution } \\
\text { - Ability to draw conclusions from statements }\end{array}$ \\
\hline
\end{tabular}

From table 15, it can be seen that the highest average score is 80.625 , namely the indicator of the ability to present mathematical statements orally, in writing, pictures, and diagrams and the ability to submit conjectures. The dikator is the ability to do mathematical manipulation, namely 67.5 . The average of the other three question numbers is $73,125,71,25$ and 75 .

\section{j. Student Disposition after Using Local Culture-Based Teaching Materials that have been Developed in Trials II}

Students 'mathematical disposition questionnaire data were collected and analyzed to determine the students' mathematical disposition abilities after the learning treatment in trial II. The choice of answer from the statement item disposition uses a linkert scale. The type of data obtained from the answers to the questionnaire is an ordinal scale. Calculations using the Successive Interval Method were carried out using Ms. software. Excel 2016. The overall results of the analysis can be seen in appendix 11. The results of descriptive analysis of students' mathematical dispositions after using learning tools are presented in Table 4:22 below:

Table 16. Description of Student's Mathematical Disposition Data after Using Learning Devices in Trial II

\begin{tabular}{|c|l|c|}
\hline No. & \multicolumn{1}{|c|}{ Indicator } & Average \\
\hline 1 & Generality & 3.37 \\
\hline 2 & Level & 3.28 \\
\hline 3 & Strength & 3.17 \\
\hline \multicolumn{2}{|c|}{ Total average } & 3.27 \\
\hline
\end{tabular}


Table 16 shows that the lowest value for behavioral indicators (generality) is 3.17. While the student's highest score on the indicator of the difficulty level of the task (level) was 3.37. Meanwhile, the indicators of stability, belief or hope (strength) were 3.28. The total average of the students' disposition abilities on trial 1 was 3.27 .

\subsection{Discussion}

To answer the formulation of research problems and how the research objectives were achieved, the following will be presented with a discussion of the research findings in the form of developing teaching materials based on local culture with a constructivism approach, mathematical reasoning abilities and mathematical dispositions.

\section{a. Teaching Material Development}

Learning requires supporting teaching materials to simplify the process. Learning in junior high school students aged 12-14 years, if referred to in Piaget's opinion, the cognitive development of students at that age is a formal operational stage. In development there is a process of assimilation and accommodation. Assimilation is a cognitive process by which a person integrates a stimulus that can change perceptions, concepts, principles or new experiences into an existing schema in his mind whereas accommodation can be in the form of forming new schemes that can match the characteristics of existing stimuli or modify a suitable scheme with the characteristics of the existing stimulus. In learning, there is a need for a balance between assimilation and accommodation.

Furthermore, Vygotsky (2009) states that learning occurs when students work to handle tasks that have not been studied but those tasks are still in the Zone of proximal development, the area lies in problem solving skills under the guidance of adults or peers who are more capable.

\section{b. Mathematical Reasoning Ability}

As stated earlier, what is meant by mathematical reasoning ability is a person's attempt to find the truth in using rules that are measured and evaluated based on the ability to think based on facts of analogy, generalization, conditionality and syllogism to produce conclusions.

The criteria for an effective device will also be seen from the achievement of student learning completeness through tests aimed at seeing how students' mathematical reasoning abilities are. This criterion is met if more or equal to $85 \%$ of students are declared to have completed fulfilling the $\mathrm{KKM} \geq 60$. Analysis of data on students 'mathematical reasoning abilities in the first trial of students' mathematical reasoning ability tests showed that 28 out of 32 students completed or $87.5 \%$. This means that 4 students or $12.5 \%$ did not complete. If referring to the criteria in CHAPTER III, the mathematical reasoning ability in the first trial has met the criteria for being effective.

In the second trial, the mathematical reasoning ability test showed that 30 out of 32 students completed or $93.75 \%$. This means that only 2 people left or $6.25 \%$ of students did not complete. Based on this, it can be concluded that the students' mathematical reasoning abilities have met the predetermined criteria. From trial I and trial 2, the students' mathematical reasoning ability increased by $6.25 \%$. This is in line with the research of Harahap et al. (2014) stated that the constructivism approach can improve logical reasoning abilities. 


\section{Conclusion}

Based on the research results that have been obtained, it is concluded that:

1. Teaching materials based on local culture developed are valid in improving the reasoning abilities and mathematical positions of students with validity levels at the interval: $4 \leq \mathrm{Va}$ $<5$ with valid criteria and a little revision

2. The local culture-based teaching materials developed were effective in improving students' rationalizing abilities and mathematical dispositions by fulfilling the five effectiveness indicators in the second trial, namely:

a. Completeness of learning on the mathematical reasoning abilities of students who get a minimum score of fulfilling $\mathrm{KM}$ or reaching $85 \%$, where in the first trial it reached $87.5 \%$ of students completed and in the second trial it reached $93.75 \%$ of students completed. $\geq 60$

b. The completeness of learning on the students' mathematical disposition ability in the first try got a value of 3.19 and in the second try it got a value of 3.27 on a scale of 4 .

c. The achievement of the percentage of the ideal time for student activities is in accordance with the predetermined,

d. The achievement of the teacher's ability to manage learning is good,

e. $85 \%$ of the many subjects studied gave a positive response to the components and learning activities.

3. The increase in students' mathematical reasoning abilities in the application of teaching materials based on local culture, namely 0.19 , with the average value of the mathematical reasoning ability test results obtained in the first trial was 2.99. Whereas in the second trial, the average value of the mathematical reasoning ability test was 3.18 .

4. The improvement of students' mathematical disposition abilities in the development of teaching materials based on local culture, namely 0.43 , with the average score of the mathematical disposition ability test in the first trial obtained was 2.73 . Whereas in the second trial, the average score of the mathematical disposition ability test results were 3.16 . 


\section{References}

Adliani, S., Asmin, and Hasratuddin. (2020). The Influence of Realistic Mathematical Approach to Understanding Concept and the Mathematical Connection Ability of Islamic Private Vocational School Students Hikmatul Fadhillah Medan Class VII. Budapest International Research and Critics in Linguistics and Education (BirLE) Journal Vol 3 (1): 487-499.

Akker, J, V, D. 1999. Principles and Methods of Development Research. In Plomp, T; Nieveen, N; Gustafson, K; Branch, RM; and Van Den Akker, J (eds). Design Approaches and Tools in Education and Training. London: Kluwer Academic Publisher.

Depdiknas. 2008. Panduan Pengembangan Bahan Ajar. Direktorat Pembinaan Sekolah Menengah Atas.

Lithner, J. 2008. A Research Framework for Creative and Imitative Reasoning. Educational Studies in Mathematics. Vol. 67, No. 3

Nasution, Y.S., Syahputra, E., and Mulyono. (2020). The Development of Learning Instrument Using Problem Based Learning Model to Improve Critical Thinking of Junior High School Students. Budapest International Research and Critics in Linguistics and Education (BirLE) Journal Vol 3 (3): 1501-1508.

Peraturan Pemerintah Nomor 13 Tahun 2015 Tentang Standar Nasional Pendidikan

Permendiknas No 16 Tahun 2007 tentang Kualifikasi Akademik dan Standar Kompetensi Guru.

Permendiknas No. 16/2007 concerning Academic Qualifications and Teacher Competency Standards.

Pohan, A.M., Asmin, Menanti, A. (2020). The Effect of Problem Based Learning and Learning Motivation of Mathematical Problem Solving Skills of Class 5 Students at SDN 0407 Mondang. Budapest International Research and Critics in Linguistics and Education (BirLE) Journal Vol 3 (1): 531-539.

Shadiq, F. 2004. Pemecahan Masalah, Penalaran, dan Komunikasi. Diklat Instruktur/ Pengembang Matematika SMA Jenjang Dasar. Kemendikbud.

Slavin, R.,E. 2005. Cooperative Learning: Teori, Riser, dan Praktek. Bandung: Nusa Media.

Sumarmo. 2012. Alternatif Pembelajaran Matematika dalam Menerapkan Kurikulum Berbasis Kompetensi. Makalah pada Seminar Tingkat Nasional FPMIPA UPI. Bandung: Universitas Pendidikan Indonesia.

Tarigan, E.E., Hasratuddin, and Fauzi, K.M.A. (2020). Development of Students Work Sheet Based on Realistic Mathematic Approach with Ethnomatematic nuanced to Improve Critical Thinking of 4th Grade Students in Primary School (SD Negeri 091358 Haranggaol, Haranggaol Horisan Sub-District). Budapest International Research and Critics in Linguistics and Education (BirLE) Journal Vol 3 (1): 133-143.

Thiagarajan, S. Semmel, DS Semmel, MI 1974. Instructional Development for Teachers of Exceptional Children. Blomington: Indiana University.

Trianto. 2009. Designing Innovative-Progressive Learning Models. Jakarta: Golden.

Undang-undang Republik Indonesia Nomor 20 Tahun 2013 Tentang Sistem Pendidikan Nasional.

Wardhani, S. 2008. SI and SKL Analysis of SMP / MTs Mathematics Subjects for Optimizing Mathematics Subjects Objectives. Yogyakarta: Center for the Development and Empowerment of Mathematics Educators and Education Personnel. 